\title{
Clinical presentation \& survival outcome of severe malaria among hospitalized children- a single centre observational study
}

\author{
Murmu M.C. ${ }^{1}$, Behera S.R. ${ }^{2}$, Satpathy S.K. ${ }^{3}$ \\ ${ }^{1}$ Dr. Mangal Charan Murmu, Assistant Professor, ${ }^{2}$ Dr. Satyaranjan Behera, Postgraduate Resident, ${ }^{3}$ Dr. Saroj Kumar \\ Satpathy, Professor and Head, all authors are affiliated with Department of Pediatrics , S.C.B. Medical College \& \\ Hospital, Cuttack, Odisha, India
}

Address for Correspondence: Dr. Mangal Charan Murmu, Email: mangal74murmu@ yahoo.co.in

\begin{abstract}
Introduction: Malaria is characterized by paroxysms of fever, chills, sweats, fatigue, anaemia\& splenomegaly. Fatality rates around 10-30 \% have been reported among children mainly due to cerebral malaria \&anaemia followed by respiratory infections, diarrheal disease \& malnutrition. Methodology: This study was done in Department of pediatrics, S.C.B medical college \& S.V.P. P.G.I.P., Cuttack, from October 2013 to September 2015 with Objectives to study the clinical presentation \& survival outcome of severe malaria in children of age group 1 to 14 yrs. A detailed history of illness, clinical examination, investigations, treatment \& responses to therapy of each case were noted in standard proforma. Results: A total of 134 children with severe malaria were studied. Maximum number of cases were seen in age group of $1-5$ years $(40.29 \%)$ followed by age group of 5-10 years (33.58\%). Male: Female ratio was 1.6:1.Fever was present in $100 \%$ of cases, altered sensorium in $50 \%$, convulsion in $49 \%$ \& jaundice in $35.82 \%$. Most of the cases were due to p. Falciparum (80.59\%). Out of 41cases of severe anemia, 22(53.65\%) survived. Out of 8 cases with respiratory distress, 1(0.74\%) survived. Out of 67 cases with CNS involvement, 45(67.16\%) survived. Out of 25 cases with Hepatopathy, 25(18.65\%) survived. Out of 47 cases of single organ involvement 45 cases survived \& 2 cases died. Out of 60 cases of multiple organ involvement 36 cases survived. Conclusion: Awareness about the changing spectrum of severe malaria is of great importance to every level for healthcare provider.
\end{abstract}

Keywords: Severe malaria, Survival outcome, Multiorgan involvement

\section{Introduction}

Malaria is characterized by paroxysms of fever, chills, sweats, fatigue, anaemia \& splenomegaly [1]. Malaria is almost as old as human race $\&$ has been described since 5th century B.C. by Hippocrates. Even Charak \& Susruta of ayurvedic period gave vivid description of its association with mosquito bite [2]. It is caused by intracellular plasmodium protozoa transmitted to humans by female anopheles mosquito. Malaria is characterized by paroxysms of fever, chills, sweats, fatigue, anaemia\& splenomegaly. Malaria is of overwhelming importance in the developing world today, with an estimated 300-500 million cases \& more than 1 million deaths each year [3]. Approximately half of global population is at risk of malaria. Fatality rates around $10-30 \%$ have been reported among children

Manuscript received: $04^{\text {th }}$ April 2017

Reviewed: $10^{\text {th }}$ April 2017

Author Corrected: $17^{\text {th }}$ April 2017

Accepted for Publication: $27^{\text {th }}$ April 2017 referred to hospital with severe malaria mainly due to cerebral malaria \&anaemia followed by respiratory infections, diarrheal disease \& malnutrition [6]. Severe falciparum malaria is defined as acute malaria with signs of severity/ occurrence of vital organ dysfunction.

In severe falciparum malaria processes of cytoadherence, resetting \& agglutination results in sequestration of $\mathrm{RBC}$ containing mature forms of the parasite in vital organs thereby interfering with microcirculatory flow leading to cerebral, cardiac, pulmonary, intestinal\& hepatic failure [4]. Severity of malaria is manifested by unarousable coma/cerebral malaria, academia/acidosis, severe normochromic normocytic anemia, renal failure, pulmonary oedema/ARDS, hypoglycemia, hypotension/shock, bleeding/ DIC, convulsions, hemoglobinuria, impaired consciousness, prostration \& hyperparasitaemia. 
Multiorgan dysfunction syndrome is defined as dysfunction of $>1$ organ, requiring intervention to maintain homeostasis $[5,6]$.

In addition to "traditional" sepsis, severe falciparum malaria is an important etiology of MODS. While uncomplicated falciparum malaria causes a mortality of about $0.1 \%$, once vital organs dysfunction occurs mortality risk rises steeply [7].

There is a paucity of studies on the different clinical presentations \& organ involvements in severe malaria among children. Hence this study was made to analyse the varied clinical presentations of severe malaria among children \&its outcome.

\section{Aims \& Objectives}

To study the clinical presentation \& survival outcome of severe malaria in children of age group 1 to 14 yrs.

\section{Materials and Methods}

This study was done in the Department of paediatrics, S.C.B medical college \&S.V.P. P.G.I.P., Cuttack, a tertiary care referral hospital from October 2013 to September 2015. It's a direct observation prospective study.

Inclusion criteria: All children between 1-14 years of age admitted to Paediatrics indoor of S.C.B.M.C. and S.V.P.P.G.I.P., Cuttack during the study period with a primary diagnosis of malaria who satisfy any 1 of WHO Criteria for severe malaria were included [8].

Exclusion criteria: Children with suspected malaria treated as severe malaria but laboratory studies were suggestive of malaria negative \& those children with similar presentation diagnosed to be due to other aetiopathological cause were excluded from the study.

In our study 134 number of cases fulfilling the inclusion criteria were taken in to study.

\section{Methodology}

A detailed history of illness, clinical examination, investigations, treatment $\&$ responses to therapy of each case were noted in standard proforma. Necessary Investigations done to reach the final diagnosis. The data were noted in tabulate form \& results were interpreted by using statistical analysis.

Blood smear preparation: Third or fourth finger of left hand is pricked at distal part of palmar aspect under all aseptic conditions (area to be pricked is wiped with alcohol\& allowed to dry).

Microscopic examination of blood film: Thin blood films- At least 100 fields to be examined for $10 \mathrm{~min}$ before discarding as MP negative. Thick blood film- It concentrates 20-30 layers of red cells on a small surface, \& detects parasitemia as low as 20 parasites $/ \mathrm{ml}$.

\section{Results}

A total of 134 children with severe malaria were studied, result of which are tabulated as below.

Table-1: Age \& sex distribution in the study group

\begin{tabular}{|c|c|c|c|c|}
\hline $\begin{array}{c}\text { Age group } \\
(\text { years })\end{array}$ & Male & Female & Total & Percentage \\
\hline $1-<5$ & $36(26.86 \%)$ & $18(13.43 \%)$ & 54 & $40.29 \%$ \\
\hline $5-<10$ & $25(18.65 \%)$ & $20(14.92 \%)$ & 45 & $33.58 \%$ \\
\hline $10-14$ & $22(16.41 \%)$ & $13(9.70 \%)$ & 35 & $26.11 \%$ \\
\hline Total & $\mathbf{8 3}(61.94 \%)$ & $\mathbf{5 1}(\mathbf{3 8 . 0 5} \%)$ & $\mathbf{1 3 4}$ & $\mathbf{1 0 0 \%}$ \\
\hline
\end{tabular}

Maximum number of cases were seen in age group of 1-5 years (40.29\%) followed by age group of 5-10 years (33.58\%). About $26.11 \%$ belonged to $10-14$ years age group. The mean age of presentation was 6.4 years. Male: Female ratio was $1.6: 1$.

Fever was present in $100 \%$ of cases, altered sensorium in $50 \%$, convulsion in $49 \%$ \& jaundice in $35.82 \%$ Prostration was found in $20.89 \%$, Hemoglobinuria was present in $5.22 \%$, Spontaneous bleeding was found in $7.46 \%$ \& decreased urination was found in $17.1 \%$ cases. 
Table-2: Presenting complaints of the patients $(n=134)$

\begin{tabular}{|c|c|c|}
\hline Presenting complaint & No of cases & Percentage (\%) \\
\hline Fever & 134 & $100 \%$ \\
\hline Altered sensorium & 67 & $50 \%$ \\
\hline Convulsion & 49 & $36.56 \%$ \\
\hline Jaundice & 48 & $5.97 \%$ \\
\hline Respiratory distress & 8 & $5.22 \%$ \\
\hline Hemoglobinuria & 7 & $17.1 \%$ \\
\hline Decreased urination & 23 & $7.46 \%$ \\
\hline Bleeding & 10 & $20.89 \%$ \\
\hline Prostration & 28 & \\
\hline
\end{tabular}

Table-3: Clinical signs of the studied cases

\begin{tabular}{|c|c|c|}
\hline Clinical signs & No of cases & Percentage \\
\hline Pallor & 113 & $84.32 \%$ \\
\hline Icterus & 55 & $41.04 \%$ \\
\hline Oedema & 21 & $15.67 \%$ \\
\hline Hepatomegaly & 122 & $93.12 \%$ \\
\hline Splenomegaly & 111 & $17.16 \%$ \\
\hline Oliguria & 23 & $50 \%$ \\
\hline GCS 11 & 67 & $17.1 \%$ \\
\hline Shock & 23 & $7.4 \%$ \\
\hline Bleeding & 10 & $5.9 \%$ \\
\hline Chest signs & 8 & $103 \%$ \\
\hline
\end{tabular}

Hepatomegaly was found in $93.12 \%$ of patients \& splenomegaly in $82.83 \%$ cases. Normal platelet count was noted in $72.38 \%$ \&Thrombocytopenia (TPC $<150,000$ ) in $27.61 \%$.TPC $<50,000$ was found in $5.22 \%$ cases. Normal Serum Creatinine was found in $5.377 \%$. Creatinine $>3 \mathrm{mg} \%$ was found in $12.68 \%$.

Mean S. Creatinine level was $1.44 \mathrm{mg} \%$. Serum Bilirubin of $<3 \mathrm{mg} / \mathrm{dl}$ was found in $68.65 \%, 3-5 \mathrm{mg} / \mathrm{dl}$ was found in $10.44 \%$, between $5-10 \mathrm{mg} / \mathrm{dl}$ was found in $8.95 \% \&>15 \mathrm{mg} / \mathrm{dl}$ in $3.73 \%$ patients. Mean bilirubin level was $3.38 \mathrm{mg} / \mathrm{dl}$. CRP was raised in $86.56 \%$ of patients.

Table-4: Distribution of cases according to presenting hemoglobin concentration $(n=134)$

\begin{tabular}{|c|c|c|}
\hline Hemoglobin in gm \% & No of cases & Percentage (\%) \\
\hline$<5$ & 41 & $30.59 \%$ \\
\hline$>5-<8$ & 35 & $26.11 \%$ \\
\hline $8-<10$ & 36 & $16.41 \%$ \\
\hline$>10$ & 22 & $\mathbf{1 0 0} \%$ \\
\hline
\end{tabular}


This table depicts distribution of cases according to the presenting hemoglobin level. 41 patients (30.59\%) cases have got severe anemia (hemoglobin <5 gm \%) where as 93 (69.40\%) cases have hemoglobin level >5gm\%.

Table-5: Parasitological parameters of severe malaria

\begin{tabular}{|c|c|c|c|}
\hline Type of species & p.falciparum & P.vivax & Mixed \\
\hline Number of cases $(\%)$ & $109(80.59 \%)$ & $2(1.49 \%)$ & $23(17.91)$ \\
\hline
\end{tabular}

Most of the cases were due to p. falciparum which accounts for $80.59 \%$, followed by mixed infection (P.f + P.v) accounting for $17.91 \%$ cases and the least by P. vivax around $1.49 \%$ of cases.

Table-6: Survival based on organ involvement

\begin{tabular}{|c|c|c|c|c|}
\hline & $\begin{array}{c}\text { Survivor Cases } \\
(\%)\end{array}$ & $\begin{array}{c}\text { Non Survivor } \\
\text { Cases (\%) }\end{array}$ & No of cases & $P$ value \\
\hline Severe Anemia $<5 \mathrm{~g} / \mathrm{dl}$ present & $22(53.65 \%)$ & $19(46.34 \%)$ & $41(30.59 \%)$ & \multirow{2}{*}{$\begin{array}{l}\text { Significant } \\
(<0.0001)\end{array}$} \\
\hline Severe anemia absent & $85(91.39 \%)$ & $8(8.6 \%)$ & $93(69.4 \%)$ & \\
\hline Respiratory distress present & $1(12.5 \%)$ & $7(87.5 \%)$ & $8(5.97 \%)$ & \multirow{2}{*}{$\begin{array}{l}\text { Significant } \\
(<0.00001)\end{array}$} \\
\hline Respiratory distress absent & $106(84.12 \%)$ & $20(15.87 \%)$ & $126(94.02 \%)$ & \\
\hline CNS involvement Present & $43(64.17 \%)$ & $22(32.83 \%)$ & & \multirow{2}{*}{$\begin{array}{c}\text { Significant } \\
(0.0003)\end{array}$} \\
\hline CNS involvement Absent & $62(92.53 \%)$ & $5(7.4 \%)$ & $67(50 \%)$ & \\
\hline $\begin{array}{c}\text { Serum Billirubin }(\mathrm{T})>3 \mathrm{mg} / \mathrm{dl} \\
\text { Present }\end{array}$ & $25(59.52 \%)$ & $17(40.47 \%)$ & $42(31.34 \%)$ & \multirow{2}{*}{$\begin{array}{l}\text { Significant } \\
(0.0001)\end{array}$} \\
\hline $\begin{array}{c}\text { Serum Billirubin }(\mathrm{T})>3 \mathrm{mg} / \mathrm{dl} \\
\text { Absent }\end{array}$ & $82(89.13 \%)$ & $10(10.8 \%)$ & $92(68.65 \%)$ & \\
\hline Sr.creatinine $>3 \mathrm{mg} / \mathrm{dl}$ Present & $10(58.82 \%)$ & $7(41.17 \%)$ & $17(12.68 \%)$ & \multirow{2}{*}{$\begin{array}{c}\text { Significant } \\
(0.0212)\end{array}$} \\
\hline Sr.creatinine $>3 \mathrm{mg} / \mathrm{dl}$ Absent & $97(82.90 \%)$ & $20(17.09 \%)$ & $117(87.31 \%)$ & \\
\hline Shock Present & $3(13.04 \%)$ & $20(86.95 \%)$ & $23(17.16 \%)$ & \multirow{2}{*}{$\begin{array}{c}\text { Significant } \\
(<0.001)\end{array}$} \\
\hline Shock Absent & $104(93.69 \%)$ & $7(6.3 \%)$ & $111(82.83 \%)$ & \\
\hline Organ involvement Present & $80(74.76 \%)$ & $27(25.23 \%)$ & $107(79.85 \%)$ & \multirow{2}{*}{$\begin{array}{c}\text { Significant } \\
(0.0036)\end{array}$} \\
\hline Organ involvement Absent & $27(100 \%)$ & $0(0 \%)$ & $27(20.14 \%)$ & \\
\hline Multi organ involvement & $36(60 \%)$ & $24(40 \%)$ & $60(56.07 \%)$ & \multirow{2}{*}{$\begin{array}{c}\text { Significant } \\
(0.0001)\end{array}$} \\
\hline Single organ involvement & $45(95.74 \%)$ & $2(4.25 \%)$ & $47(43.92 \%)$ & \\
\hline
\end{tabular}

The table shows significant association of anaemia, involvement of respiratory system, CNS , hepatic, renal, multiorgan system, including Shock on survival.

\section{Discussion}

In our study majority were between $1-5$ years $(40.29 \%)$ \& between $5-10$ years $(33.58 \%)$ which was similar to other studies $[9,10]$. We observed that males outnumbered females in all age groups. There were a total of 83 males $(61.94 \%) \& 51$ females $(38.05 \%)$ with the male: female ratio of $1.62: 1$ which was similar to other studies $[10,11,12,13,14,15]$. The sex difference may be explained due to medical care seeking behaviour in different socioeconomic status ethnic groups, attitude of parents especially mothers towards 
male children, more outdoor activity of males \& better clothing of females in India.

Most common presentation was fever which was similar to other studies $[10,6,7,8,9,10,11]$. Other predominant symptoms were altered sensorium $(50 \%)$ \& convulsion (36.56\%)which were comparable to other studies $[10,13,14,15,19]$. Jaundice was present in $41.04 \%$ which was comparable to other studies $[11,20]$.

Presence of raised serum bilirubin not only indicates hemolysis but also liver dysfunction. Prostration, defined as the inability to sit unsupported (for children over 6 months of age) or the inability to drink or breast-feed in younger children was found in $20.89 \%$ of the cases as against around $40 \%$ in other studies [13,21].

Shock as described as $\mathrm{SBP}<70 \mathrm{~mm} \mathrm{Hg}$ or need of Isotonic IV Fluid bolus $\geq 40 \mathrm{ml} / \mathrm{kg}$ in $1 \mathrm{hr}$ need for vasoactive drug to maintain $\mathrm{BP}$ in normal range (dopamine $>5 \mu \mathrm{g} / \mathrm{kg} / \mathrm{min}$ or dobutamine, epinephrine, or norepinephrine at any dose was found in $17.1 \%$ ) as against $10 \%$ in other studies [14,22]. Pallor was found in $84.32 \%$ cases similar to other study [14].

Majority of cases had hepatosplenomegaly with hepatomegaly in $93.12 \%$ \& splenomegaly in $82.83 \%$ cases which was consistent with other studies $[14,16$, 23]. Hemoglobinuria was present in $5.22 \%$ which was comparable to other studies $[10,11,15,21,24]$.

Respiratory distress as described by tachypnea \&deep breathing with use of accessory muscles of respiration \& chest recession was found $5.97 \%$ which was comparable to other studies $[11,13,15]$. However higher incidence between $25-40 \%$ were noted in some studies $[9,19,21,25]$.

Spontaneous bleeding was found in $7.46 \%$ which was similar to some studies $[14,15]$ \& slightly more than other studies [11,21]. Oliguria was found in $17.16 \%$ cases which is slightly more than other studies [10,13]. In our study $74.62 \%$ cases had some degree of anemia whereas $25.37 \%$ had severe anemia (hemoglobin $<5$ gm $\%$ which was similar to other studies $[11,13,14,19,21,26,27,28]$.

Leucocytosis TLC> $15,000 / \mathrm{cmm}$ was found in $13.43 \%$ which was comparable to other studies [15,29]. Thrombocytopenia (TPC <150,000) was found in $27.6 \%$ patients whereas $\mathrm{TPC}<50,000$ was found in $5.22 \%$ cases which was comparable to another study [1]. Renal failure (S.Creatinine $>3 \mathrm{mg} \%$ ) was found in
$12.68 \%$ which was similar to other studies [3,21]. Hepatopathy (S.Bilirubin> $3 \mathrm{mg} \%$ ) was found in 31.34 $\%$ which was comparable to other studies $[3,17,18,26]$.

Out of $25.37 \%$ cases of severe anemia $14.17 \%$ died whereas $11.19 \%$ cases survived. Severe anemia was a major predictor of fatal outcome with a significant $\mathrm{p}$ value $<0.05$ which matches other studies $[17,22,26]$.We observed that out of $5.97 \%$ with respiratory distress only 1 survived while 7 did not.

Respiratory distress was another key presenting feature of childhood malaria with a very high mortality rate $(66.7 \%)$ which was similar to other studies [ 1718,27,28 ]. Among $50 \%$ patients of CNS involvement $16.41 \%$ died whereas $33.58 \%$ cases survived which matched other studies [10,19].Out of 107 patients with organ dysfunction $59.70 \%$ survived whereas $20.17 \%$ did not.

All 27 patients $(20.14 \%)$ without any organ dysfunction survived. Multi organ involvement was associated with higher morbidity\& mortality which was similar to other studies $[19,28]$.

\section{Conclusion}

Awareness about the changing spectrum of severe malaria is of great importance to every level healthcare provider. Today, in India with any level of transmission the possibility of falciparum malaria should always be suspected in a patient presenting with fever along with jaundice or renal failure.

P. vivax is emerging as an important cause of malarial morbidity \&mortality. Besides shock, cerebral malaria \& severe anemia which have been implicated even in the past as predictors of complications in severe malaria, hepatic involvement\& renal failure also have emerged with significant impact over the course of the disease.

\section{Abbreviations}

ABG- Arterial Blood Gas, ALP- Alkaline Phosphatase, ARDS- Acute Respiratory Distress Syndrome, BPBlood Pressure, B.C.- Before Christm, Cmm- Cubic Millimeter, CRP- C- Reactive Protein, CSFCerebrospinal Fluid, C/S- Culture Sensitivity, DCDifferential Count, DIC- Disseminated Intravascular Coagulation, ECG- Electrocardiogram, GCS- Glascow Coma Scale, Hb - Haemoglobin, HBsAg- Hepatitis B Surface Antigen, ICT- Immunochromatographic Test, IV- Intra Venous, LFT- Liver Function Test, Min- 
Minute, Ml- Millilitre, Mp- Malaria Parasite, PsPeripheral Smear, QBC- Quantitative Buffy Coat, RBC- Red Blood Cell, RBS- Random Blood Sugar, RE- Routine Examination, SBP- Systolic Blood Pressure, SGOT- Serum Glutamic Oxaloacetic Transaminase, SGPT- Serum Glutamic Pyruvic Transaminase, TPC- Total Platelet Count, TLC- Total Leucocyte Count, USG- Ultrasonogram, WHO- World Health Organisation

Funding: Nil, Conflict of interest: None initiated, Perission from IRB: Yes

\section{Reference}

1. Chandy C. John, Peter J. Krause , Malaria (Plasmodium) Chapter 280

2. David A. Warrell, Herbert M Gilles, Herbert A. Gilles, Herbert M. Gilles ,Essential Malariology / Edition 4,2002; 1-25.

3. Management for severe Malaria,third edition(WHO),2012, A practical hand book.

4. Goldstein B, Giroir B, Randolph A. International pediatric sepsis consensus conference: definitions for sepsis and organ dysfunction in pediatrics. Pediatr Crit Care Med. 2005 Jan;6(1):2-8.

5. Cook G C, Zumla A. Manson's tropical Diseases $22^{\text {nd }}$ Edn.2009

\section{NMEP Publication, Govt. of India.}

7. Goldstein B, Giroir B, Randolph A, the International pediatric sepsis consensus conference: Definitions for sepsis and organ dysfunction in pediatrics. Pediatr Crit Care Med 2005; Vol. 6: 2-8

8. Herlihy JM, D'Acremont V, Hay Burgess DC, Hamer DH. Diagnosis and Treatment of the Febrile Child.

9. Abdullah Al-Taiar, Shabbar Jaffar, Ali Assabri. Severe malaria in children in Yemen: Two site observational study. BMJ 333(7573):827 • November 2006. DOI: 10.1136/bmj.38959.368819

10. Gohiya P, Goel M, Dwevedi R, Renwal S. Clinical profile and prognostic indicators of Plasmodium Falciparum Malaria in children. Int J Med Res Rev 2014;2(3):215- 220.doi:10.17511/ijmrr.2014.i03.011
11. Satpathy SK, Mohanty N, Nanda P, Samal G. Severe falciparum malaria. Indian J Pediatr. 2004 Feb;71(2):133-5.

12. Pramila Verma, Shweta Anand, Anju Kapoor. Predictors of fatal outcome of severe malaria in children of Bhopal, Central India: Retrospective study.Sri Lanka Journal of Child Health, 2015; 44(1): 17-23.

13. Tusti Ganguly, Asok Kumar Datta, Syamali Mandal, Pradip Kumar Das. Clinicoparasitological Study of Acute Severe Malaria in Children. Journal of Pharmacy and Biological Sciences 2012;2(6): 12-21.

14. Jaya Shankar Kaushik, Sunil Gomber, Pooja Dewan Clinical and Epidemiological Profiles of Severe Malaria in Children from Delhi, India. Journal of Pharmacy and Biological Science.2012;2(6):113-116.

15. P. Verma, U. S. Shukla, A. Kalraiya, Retrospective Study on Clinical Profile of Severe Malaria in Children Admitted in a Tertiary Care Centre of Central India. People's Journal of Scientific Research, 2014;7(1):2329.

16. Chandar V, Mehta SR, Sharma PD, Sarkar PK, Sharma BR. Falciparum malaria. Indian J Pediatr. 1989 May-Jun;56(3):365-9.

17. Raveendra K, Prabhu. Study on a Typical Manifestations in Malaria at a Tertiary Referral Centre in Bangalore; International Journal of Science and Research. Volume 4 Issue 1, January 2015.

18. Amar Taksande, KrishnaVilhekar, Manish Jain, SuchitaAtkari. Clinico-haematological Profile of Cerebral Malaria in a Rural Hospital. Journal of Indian Academy of Clinical Medicine. 2006; 7(4): 308-12

19. Ahmed S, Adil F, Shahzad T, Yahiya Y. Severe malaria in children: factors predictive of outcome and response to Quinine. J Pak Med Assoc. 2011 Jan;61(1):54-8.

20. Pankaj P Taviad, T B Javadekar, Bhavna A Selot,Vipul P Chaudhary .Socio Demographic and clinical features of the Malaria Cases.National Journal of community Medicine.2012;3(1):94-96

21. Tripathy R, Parida S, Das L, Mishra DP, Tripathy D, Das MC, Chen H, Maguire JH, Panigrahi P. Clinical 
manifestations and predictors of severe malaria in Indian children. Pediatrics. 2007 Sep;120(3):e454-60.

22. Mockenhaupt F P, Ehrhardt S, Burkhardt J, Bosomtwe S Y, Laryea S, Anemana S D, Rowland N. Otchwemah, Jakob P. Cramer, Ekkehart Dietz, Sabine Gellert, Ulrich Bienzle. Manifestation and Outcome of Severe Malaria in Children in Northern Ghana. Am. J. Trop. Med. Hyg., 71(2), 2004, pp. 167-172.

23. Ahmad SH, Kidwai $\mathrm{T}$, Moonis $\mathrm{R}$, Shahab $\mathrm{T}$, Chandra J. Clinical profile of malaria in children-a prospective study from Aligarh (N. India). Ann Trop Paediatr. 1987 Jun;7(2):82-6.

24. Zeidan Z, Kajal HAI, HarbourA, Notary K, Hashim F, Awadelkarim M. Clinical and epidemiological features of severe malaria in children in four hospitals in Sudan. Eastern Mediterranean Health Journal, Vol. 12, No. 6, 2006.

25.Giha HA, Elghazali G, A-Elgadir TM, A-Elbasit IE, Eltahir EM, Baraka OZ, Khier MM, Adam I, TroyeBlomberg M, Theander TG, Elbashir MI. Clinical pattern of severe Plasmodium falciparum malaria in
Sudan in an area characterized by seasonal and unstable malaria transmission. Trans R Soc Trop Med Hyg. 2005 Apr;99(4):243-51.

26. Allen S J, O'Donnell A, Alexander N D E, Clegg JB. Severe malaria in children in Papua New Guinea. QJM: An International Journal of Medicine. Volume 89, Issue 10 Pp. 779-788.

27. Marsh K, Forster D, Waruiru C, Mwangi I, Winstanley M, Marsh V, Newton C, Winstanley P, Warn P, Peshu N, et al. Indicators of life-threatening malaria in African children. N Engl J Med. 1995 May 25;332(21):1399-404.

28. Sharma SK, Das RK, Das BK, Das PK. Haematological and coagulation profile in acute falciparum malaria. J Assoc Physicians India. 1992 Sep;40(9):581-3.

29. Banzal S, Ayoola E A, E.E. El Sammani, S.I. Rahim,P. Subramaniam, M.O.E. Gadour, A.K. Jain. The clinical pattern and complications of severe malaria in the Gizan region of Saudi Arabia. Annals of Saudi Medicine, Vol 19, No 4, 1999:378-390.

\section{How to cite this article?}

Murmu M.C., Behera S.R., Satpathy S.K. Clinical presentation \& survival outcome of severe malaria among hospitalized children- a single centre observational study. J PediatrRes.2017;4(05):315-321.doi:10. 17511/ijpr.2017.i05.05 